\title{
Understanding and overcoming baseline isotopic variability in
}

\section{running waters}

Timothy D. Jardine ${ }^{1}$, Wade L. Hadwen ${ }^{1}$, Stephen K. Hamilton ${ }^{2}$, Sally Hladyz ${ }^{3}$, Simon

M. Mitrovic ${ }^{4,5}$, Karen A. Kidd ${ }^{6}$, Wing Y. Tsoi ${ }^{1}$, Mark Spears ${ }^{1}$, Douglas P.

Westhorpe ${ }^{4,5}$, Vanessa M. Fry ${ }^{1}$, Fran Sheldon ${ }^{1}$, and Stuart E. Bunn ${ }^{1}$

${ }^{1}$ Australian Rivers Institute, Griffith University, Nathan, QLD Australia

${ }^{2}$ Kellogg Biological Station, Michigan State University, Hickory Corners, MI, USA

${ }^{3}$ CSIRO Land and Water, The Murray-Darling Freshwater Research Centre,

Wodonga, VIC Australia

${ }^{4}$ Environmental Sciences, University of Technology Sydney, Broadway, NSW,

Australia

${ }^{5}$ New South Wales Office of Water, Armidale, NSW, Australia

${ }^{6}$ Canadian Rivers Institute, University of New Brunswick, Saint John, NB, Canada

*author for correspondence: t.jardine@ griffith.edu.au 


\section{Abstract}

Natural abundances of stable isotopes in lotic food webs yield valuable information about sources of organic matter for consumers and trophic structure. However, interpretation of isotopic information can be challenging in the face of variability in organisms at the base of food webs. Unionid and dreissenid mussels, commonly used as baseline organisms in lakes, are uncommon in many river settings and can have variable diets, thus making them unsuitable as a universal baseline for many river food web studies and often forcing reliance on more common benthic insects for this purpose. Turnover rates of body carbon and nitrogen in insects are relatively rapid (1 to 50 days half life). These rapid turnover rates in primary consumers can result in considerable temporal variability in $\delta^{13} \mathrm{C}$ that rivals that of algae $(>10 \%$ range within a site). This suggests that using primary consumers as a surrogate baseline for algae may not circumvent the problem of temporal variability and the resultant mismatch of sources with longer-lived, slow-growing secondary and tertiary consumers. There are several strategies for reducing the influence of these confounding factors when bivalves with a known diet are not present. These include sampling over large spatial scales and correlating $\delta^{13} \mathrm{C}$ of consumers with the source of interest (e.g. benthic algae), sampling baseline organisms multiple times in the weeks preceding sampling of larger consumers (particularly in response to large changes in discharge), and using algal-detrital separation methods and multiple tracers as much as possible. Incorporating some of these recommendations and further exploring variability at the base of the food web will potentially provide greater insights into consumer-resource coupling in running waters and more robust conclusions about food web structure and energy flow in these dynamic systems. 
Key words: bivalves, insects, turnover, temporal variability, food web pathways, organic matter sources

\section{Introduction}

The natural abundance of stable isotopes in consumers reveals information about energy provenance, food web structure and habitat use (Fry, 2006). Several assumptions underpin the interpretation of isotopic information, most notably variable diet-tissue fractionation within and among consumers (Post, 2002; Jardine et al., 2006). While some of these assumptions are often explicitly stated and addressed, others are rarely discussed. Critical examination and communication of these assumptions can help avoid misinterpretation of isotopic data (Wolf et al., 2009).

Potential pitfalls in interpretation of stable isotope patterns may be particularly acute in food web studies of running waters because of the dynamic nature of these systems (e.g. hydrological variability, organic matter inputs, floodplain connectivity). Approaches that account for within- and among-system variation in $\delta^{15} \mathrm{~N}$ and $\delta^{13} \mathrm{C}$ of the organic matter sources that support food webs (Vander Zanden and Rasmussen, 1999; Post, 2002) have been successfully employed in lacustrine and marine environments (Post et al., 2000; Jennings et al., 2002), yet studies in running waters continue to be beset by uncertainty in the isotopic composition of basal sources that can inhibit the effective use of isotopes (France, 1995; Finlay, 2001). Despite these challenges, stable isotope analysis (SIA) of carbon, nitrogen, and more recently hydrogen and sulphur, increasingly provide new insights into dietary habits and sources of organic matter for metazoan consumers, food chain lengths, and biogeochemical cycling in streams and rivers (Perry et al., 2003; Reid et al., 2008; Walters and Post, 2008; Walters et al., 2008) and their use will undoubtedly continue 
to grow. Hidden behind these successful applications of SIA in running waters are numerous unpublished studies where data are difficult to interpret because of insufficient sampling of sources or key consumer groups.

One of the most notable challenges facing stream ecologists using isotopes is the spatiotemporal variability in isotope ratios of in-stream primary producers (i.e. periphyton) (Finlay, 2004; Hadwen et al., 2010) and its contamination by detritus (Hamilton et al. 2005). Much has been written about the spatial component of isotopic variability, with variability in $\delta^{13} \mathrm{C}$ occurring among streams, reaches within a stream, or even within a reach (e.g. France, 1995) and current methods attempt to take into account some of the $\delta^{13} \mathrm{C}$ "patchiness" in running waters by either measuring water velocity to standardize across sites (Rasmussen and Trudeau, 2010), limiting sampling to either pools or riffles (Finlay et al. 2002), or amalgamating samples from representative habitats (pools and riffles) to produce an average value for a given reach (e.g. Jardine et al., 2008). However, temporal isotopic variability is both less well understood and acknowledged (Hadwen et al., 2010; Hladyz et al., 2010).

One of the proposed solutions to the challenges posed by primary producers (spatiotemporal variability, impure samples of microalgae, and herbivore $\mathrm{N}$ isotope fractionation) is to select representative primary consumers that are known to feed on the sources of interest (Anderson and Cabana, 2007) and employ them as indicators of algal isotope ratios (Finlay et al., 1999; Walters and Post, 2008; Olsson et al., 2009). This technique makes the assumption, among others, that primary consumer isotope ratios are less temporally variable than those of algae (Cabana and Rasmussen, 1996), yet few data are available to support this. Given that many stable isotope studies in streams employ single-event sampling (e.g. Jardine et al., 2008; McHugh et al., 2010), the growing appreciation of seasonal variability in different food web 
components suggests that it is important to characterize temporal isotopic variability (Hadwen et al., 2010; Hladyz et al., 2010).

In this paper we address the relative advantages and disadvantages of using primary producers or primary consumers as isotopic baselines in food web studies of running waters. First we present empirical presence/absence data for bivalves (the most frequently nominated primary consumer to indicate baseline isotopic ratios) in rivers. We then combine published and unpublished data on turnover rates and resultant temporal isotopic variability in algae and primary consumers from divergent riverine systems (temperate and subtropical, hydrologically stable and dynamic) to compare their utility. We finish by offering some recommendations to help account for the confounding factors associated with the use of stable isotopes in studies of river food webs.

\section{Methods}

\section{Bivalve occurrence}

To determine the frequency of occurrence of bivalve molluscs in standard benthological samples, we analyzed presence/absence data for freshwater mussels from 63 sites in New Brunswick (Canada) that were sampled as part of a broader food web stable isotope study (Jardine et al., 2008). These samples were collected with a D-frame kick net in riffles and runs by disturbing the stream bed. A comparable macroinvertebrate dataset from Australia, derived from surveys using identical sampling methods, was also examined to establish the relative frequency of occurrence for bivalves in streams in sub-tropical Australia. These data, from the Ecosystem Health Monitoring Program (EHMP) in southeast Queensland, include 
macroinvertebrate collections from up to 132 sites, sampled twice yearly between 2002 and 2007 (Bunn et al., 2010).

\section{Turnover rates}

To assess the time scales of isotopic change in food webs, half-lives of carbon and nitrogen in primary producers and consumers in streams were estimated from the literature (Table 1). Half-lives are calculated by fitting an exponential model to isotope data plotted through time following a diet switch (Hobson and Clark, 1992). The equations take the form: $\mathrm{y}=\mathrm{b}+\mathrm{a}^{*} e^{\mathrm{ct}}$ where $\mathrm{t}$ is the time in days since the diet switch (or the addition of tracer) and $\mathrm{c}$ is the derived constant. This constant can then be entered in the formula: half-life $=\ln (0.5) / \mathrm{c}$ to yield a half-life estimate (Hobson and Clark, 1992). When data were not amenable to calculations of this type, halflives were roughly estimated from figures provided (e.g. Doi et al., 2007). Most of the available information on elemental turnover comes from ${ }^{15} \mathrm{~N}$ addition experiments and thus represents nitrogen, which may turn over at different rates than carbon or other elements (Jardine et al., 2008). However, differences between elements are likely to be small compared with differences among organisms or tissues; thus, there is reason to suspect that similar trends would emerge for C.

To simulate the response of biota with different turnover rates to a hypothetical change in algal isotope ratios, we adapted a compartment model from Hamilton et al. (2004). A $\delta^{15} \mathrm{~N}$ increase of 5\% in the dissolved $\mathrm{N}$ source was introduced and the resultant changes in $\delta^{15} \mathrm{~N}$ of algae (turnover rate $=0.07 \mathrm{~d}^{-1}$ ), two benthic insects (mayflies, turnover rate $=0.26 \mathrm{~d}^{-1}$, and beetle larvae, turnover rate $=$ $0.06 \mathrm{~d}^{-1}$, representative of selected primary consumers), and unionid mussels (Pleurobema sintoxia, turnover rate in muscle $=0.003 \mathrm{~d}^{-1}$ ) were simulated. These 
turnover rates are estimates based on empirical data, they include a trophic fractionation for the three consumers of 3.3\% (Hamilton et al., 2001, 2004), and the model assumes that $100 \%$ of the diet is derived from algae. The increase was then removed after 25 days, thereby simulating a change in algal $\delta^{13} \mathrm{C}$ or $\delta^{15} \mathrm{~N}$ (McCutchan and Lewis, 2002; Hadwen et al., 2010) that can occur as a result of changes in flow rates, $\mathrm{CO}_{2}$ supply or nutrient inputs (Ostrom et al. 1998, Finlay 2004)

\section{Temporal variability}

To examine seasonal variation in isotope ratios of primary producers and consumers, we collated data from published and unpublished stream and river studies in diverse settings (Table 2). Data sources are derived from collections in eastern Canada and eastern Australia, consisting of sites sampled at varying temporal intervals (weekly to bi-monthly) and covering periods ranging from two to 12 months (Table 2). These sites encompass the range of hydrological conditions seen in rivers, from highly stable to unpredictable (Puckridge et al., 1998). The Canadian streams are temperate, forested headwaters with spring and autumn peaks in discharge associated with snowmelt and precipitation, respectively. During summer, baseflow is relatively stable with a slow decline from May to October when sampling was conducted. The Australian systems include subtropical streams in forested and urbanized catchments in southeast Queensland and temperate rivers in the northern and southern parts of the Murray-Darling Basin, Australia's largest catchment. Most of these lotic sites are far more hydrologically variable than their Canadian counterparts, with large flows typically (but not always) occurring in either the summer months (December to February, SE Queensland) or winter/spring (June to November, southern Murray Darling system). They also have somewhat 
unpredictable flows that occur throughout the year depending on sporadic rainfall and releases from dams in regulated systems (e.g. Murrumbidgee River). Sampling occurred over a range of flow conditions in these rivers throughout the year, but system-specific discharge data was unavailable.

Biofilm scrubbed from rocks and other surfaces (wood, mud) is a complex mixture of attached algae (periphyton), bacteria, fungi, small invertebrates and nonliving organic matter (Lock, 1981). In this study we restricted our analyses to the evaluation of variability in biofilm and attached filamentous algae because they are the primary producers most commonly sampled in streams and small rivers. Though they may be important in some river settings, we did not focus on aquatic vascular plants or phytoplankton because they are less commonly sampled in running waters and in our data sets they were not analysed often enough to permit temporal analyses. Sampling procedures differed among studies; those reported here are examples of how primary producers and consumers are typically collected for SIA in riverine studies. In the Canadian streams, a minimum of three biofilm samples per site was collected and values averaged for a given site and time. Each of these three samples consisted of material from the non-embedded surface of three rocks, and the three samples were taken across representative areas of the stream reach (typically $\sim 100 \mathrm{~m}$ long) including both pools and riffles. Given the known heterogeneity of algal $\delta^{13} \mathrm{C}$ in pools and riffles (Finlay et al., 2002), this approach attempted to capture the mean value for algae growing in the reach. Primary consumers include all taxa collected on a given date that are typically considered scrapers or grazers (Merritt and Cummins, 1996; Gooderham and Tsyrlin, 2002). This includes mayflies (e.g. Heptageniidae), water pennies (Psephenidae), shrimps (Atyidae), and others used previously in food web studies (Anderson and Cabana, 2007), but the composition of the primary 
consumer community differed among sites and times. Consumers were collected from pools and riffles and, similar to algae, multiple samples were analysed and averaged within a site. Guts were cleared for a brief period of several hours prior to freezing.

For the Australian systems in southeast Queensland and northern New South Wales and northern Victoria, at least three replicate samples of food web components were collected at each site on each date. The length of study reaches ranged from 20 to $35 \mathrm{~m}$. Triplicate benthic algal samples (biofilm and filamentous algae categories described above) were collected from pools, runs and riffles, and from a range of different substrata (typically cobbles and submerged wood). As in the Canadian studies, means across all habitats were calculated to characterize reach-scale isotopic values, and primary consumers belonging to grazer and scraper feeding guilds were included in the analyses and collected in a similar manner.

All data presented here were generated by combusting samples in a Carlo Erba NC2500 elemental analyser coupled to a Thermo Finnigan Delta Plus mass spectrometer (University of New Brunswick, Fredericton, Canada) or a Eurovector EA 3000 coupled to an Isoprime mass spectrometer (Griffith University, Brisbane, Australia). Internal standards run repeatedly to monitor accuracy and precision yielded $\delta^{13}$ C S.D. $=0.2 \%, \delta^{15}$ N S.D. $=0.3 \%$, \%C S.D. $=1.5 \%, \%$ N S.D. $=0.5 \%(\mathrm{n}=$ 10, dragonfly larvae at University of New Brunswick) and $\delta^{13}$ C S.D. $=0.2 \%$, $\delta^{15} \mathrm{~N}$ S.D. $=0.4 \%$, \%C S.D. $=2.6 \%, \%$ N S.D. $=0.9 \%(n=29$, fish muscle at Griffith University).

Variability in time in algae or primary consumers at a given site is presented both as one standard deviation around the overall mean for the sampling period, and the range of mean values observed over the sampling period. Replicate samples of 
algae or consumers on a given sampling day were averaged and the range and standard deviations of these averages within a site were used as the measure of variability. Ranges therefore represent the range of mean values for a given site sampled through time, rather than the range in individual replicates collected over the entire study period. For context, extremes in temporal variability were compared with spatial variability within and among sites (France, 1995). For those locations where we had data for both primary producers and primary consumers, we ran paired t-tests to determine if temporal variability was higher in one of these groups (using the range in values as the dependent variable). To determine if sites with high variability in algal isotope ratios also had high variability in primary consumer isotope ratios, we regressed ranges in $\delta^{13} \mathrm{C}$ and $\delta^{15} \mathrm{~N}$ of consumers against that of algae, with site as the unit of replication. Finally, we assessed whether, in the face of such high temporal variability, there remained strong links between algal isotope ratios and primary consumer isotope ratios by regressing site-specific overall means of consumers against that of algae for both $\delta^{13} \mathrm{C}$ and $\delta^{15} \mathrm{~N}$.

\section{Results}

\section{Bivalve occurrence}

Bivalve molluscs appeared in only six of 63 sites $(9.5 \%)$ in the Canadian survey over three years of sampling. Although the incidence of occurrence for bivalves in the southeast Queensland dataset was much higher, less than half of the sites $(48 \%)$ had bivalves.

\section{Turnover Rates}


Turnover rates, based mainly on ${ }^{15} \mathrm{~N}$, were relatively fast in benthic organisms of streams (Table 1). Short-lived animals such as blackflies, mayflies, caddisflies and chironomids had fast elemental turnover with half-lives ranging between one and six days, while snails showed slower turnover rates (half-lives $>20$ days). Amphipods and beetle larvae exhibited intermediate turnover rates (11 to 21 days). Large mussels can have very slow turnover rates (e.g. muscle tissue half-life $=231$ days), similar to fish and other vertebrates, but sampling faster-turnover tissues (e.g. digestive glands, half-life $=$ four days, Table 1 ) can make them more comparable to whole-body samples of smaller organisms (Raikow and Hamilton, 2001).

The model predicted that an increase in $\delta^{15} \mathrm{~N}$ of 5\%o lasting for 25 days would result in almost immediate changes in $\delta^{15} \mathrm{~N}$ of algae, followed soon after by increases in the $\delta^{15} \mathrm{~N}$ of insect larvae (Fig. 1). The algae came closest to steady-state equilibrium with their $\mathrm{N}$ source, but values for insects remained lower than the new steady state $\delta^{15} \mathrm{~N}$ (i.e. $13.3 \%$ ) by the end of day 30 . The bivalve muscle tissue, however, showed almost no response ( $\sim 0.3 \%$ increase) to the increase in $\delta^{15} \mathrm{~N}$ because of the very slow turnover rate of this tissue. The mean value for algae for the entire 115 experimental period was $6.1 \pm 1.4 \%$ S.D. but rapid turnover and isotopic change meant that an algal sample collected on a single day (as is typical in an isotope field study) from day 5 to day 120 would almost always have a d15N value that was higher (e.g. 9.2\%o on day 30) or lower (e.g. 5.0\%o from day 90 onwards) than the mean for the period. . Only on days 7, 8 and 44 to 52 would the sampled value be within $0.3 \%$ of the mean for the period $(0.3 \%$ being the typical analytical error for $\left.\delta^{15} \mathrm{~N}\right)$. Likewise, for mayflies with rapid turnover rates, the value measured on a given day would be within $0.3 \%$ of the mean value for the period $(9.4 \pm 1.3 \%$ S.D.) only on days $9,10,11$ and 48 to 56 . For beetle larvae with intermediate turnover 
rates, only on days 14 to 19 , and 59 to 73 would the sampled value match the mean value for the period $(9.4 \pm 1.2 \%$ S.D. $)$. However, for a sample with a slower turnover rate such as the muscle tissue of a bivalve, the measured value on any day in the 115 day period would be within $0.3 \%$ of the mean value for the period $(8.6 \pm$ 0.1\% S.D., Fig. 1).

\section{Temporal Variability}

Temporal variability in isotope ratios of algae and primary consumers was high at some sites but relatively low at others (Table 2, two examples in Fig. 2). Ranges in $\delta^{13} \mathrm{C}$ of up to $15 \%$ across sampling periods occurred in some of the Australian rivers (both subtropical and temperate), corresponding to standard deviations around the overall mean of almost 5\%. This variation was in many cases marked over short time periods, with shifts of up to 5\%o occurring over a period as short as two weeks (Fig. 2).

There was no difference in the temporal variability of primary producer and consumer isotope ratios. The site-specific ranges in $\delta^{13} \mathrm{C}$ of algae were similar compared with that of primary consumers $(t=1.23, p=0.234$, Fig. 3a), and the sitespecific ranges in $\delta^{15} \mathrm{~N}$ also did not differ between the two groups $(\mathrm{t}=-0.23, \mathrm{p}=$ 0.590, Fig. 3b). Surprisingly, the $\delta^{13} \mathrm{C}$ variability (range) in algae did not predict $\delta^{13} \mathrm{C}$ variability in primary consumers $\left(r^{2}=0.12, p=0.130\right.$, Fig. 3a). However, there was a significant association between the range in $\delta^{15} \mathrm{~N}$ of primary producers and that of consumers $\left(r^{2}=0.47, p=0.001\right.$, Fig. $\left.3 b\right)$. Despite the high temporal variability in algal $\delta^{13} \mathrm{C}$ and $\delta^{15} \mathrm{~N}$, site-specific mean algal $\delta^{13} \mathrm{C}$ predicted site-specific mean primary consumer $\delta^{13} \mathrm{C}\left(\mathrm{r}^{2}=0.51, \mathrm{p}<0.001\right.$, Fig. 4a), and the relationship between these variables was even stronger for $\delta^{15} \mathrm{~N}\left(\mathrm{r}^{2}=0.78, \mathrm{p}<0.001\right.$, Fig. $\left.4 \mathrm{~b}\right)$. 


\section{Discussion}

The use of SIA to resolve food web patterns in streams has become a standard tool for aquatic ecologists but many of these isotopic studies produce results that are difficult to interpret. To improve this outcome here we discuss issues and make recommendations that will lead to more robust conclusions about sources of organic matter (assessed using carbon stable isotopes) and food chain length (assessed using nitrogen stable isotopes) in running waters.

A possible solution to the problems associated with spatial and temporal variability in lower trophic levels is to collect long-lived primary consumers such as suspension-feeding bivalve molluscs to provide an indicator of the isotopic ratios of the microalgal food resource (Howard et al., 2005; Gustafson et al., 2007). Turnover modelling in the current study supports this choice because these longer-lived organisms provide a long-term baseline average for $\delta^{15} \mathrm{~N}$ that can be better related to top predators that themselves exhibit slow turnover (Cabana and Rasmussen 1996). This approach has been used successfully in lakes (Post, 2002) and is an ideal option for baseline isotopic assessment in streams and rivers when bivalves are present and their diet is well known. Mussels can be uncommon and/or patchy in many streams and rivers (Bogan, 1993; Anderson and Cabana, 2007), and even in areas where they are common (e.g. southeast United States, Atkinson et al., 2010) their dietary preferences are highly variable and in many cases unknown. They often consume and assimilate fine particulate organic matter that is itself a mix of terrestrial and algal material (Raikow and Hamilton, 2001; Atkinson et al., 2009). As such, they are useful representatives as baseline organisms for food chain length studies because they represent the "average" baseline $\delta^{15} \mathrm{~N}$ for the food web, but they are less suitable 
as an end-member to discriminate amongst organic matter sources (e.g. algae versus leaf litter) with $\delta^{13} \mathrm{C}$, the latter being a more common question answered with isotopes in streams and rivers (Hamilton et al. 1992, France 1995, Finlay et al. 2002, McCutchan and Lewis 2002, Bunn et al. 2003, Perry et al. 2003, Doucett et al. 2007, Jardine et al. 2008, Reid et al. 2008, Hadwen et al. 2010, Hladyz et al. 2010). When lacking an obvious long-lived consumer to serve as a baseline in streams and rivers, we are faced with two options - 1) measuring algae as the base of the food web, or 2) measuring benthic insects as the base of the food web. While both of these options present their own unique challenges, the common feature of both is a high degree of temporal variability related to rapid turnover of $\mathrm{C}$ and $\mathrm{N}$ in tissues.

Previous studies have shown a rapid response of primary producers and consumers to ${ }^{15} \mathrm{~N}$ tracer additions (Mullholland et al., 2000; Hamilton et al., 2004; Hadwen and Bunn, 2005), suggesting fast turnover of body $\mathrm{N}$ (and associated C) in short-lived aquatic biota (Cabana and Rasmussen, 1996). Consumers with short life spans (e.g. blackflies and mayflies, Table 1) are likely to respond quickly to isotopic changes in primary producers because their relative growth rates are rapid (Fig. 1). Furthermore, because of the relative synchrony in the turnover rates (Table 1) and resultant isotope ratios of algae and short-lived primary consumers (Finlay 2001; McCutchan and Lewis 2002, Fig. 1), neither group may be adequate at representing the long-term average for these resources; yet the long-term average is more appropriate to match with isotope ratios of higher-order consumers with slow turnover rates (O'Reilly et al. 2002). An empirical example of this is shown in Fig. 5 (modified from Jardine et al., 2009a). Benthic feeding sculpin (Cottus sp.) with an invertebrate diet and limited mobility (Rasmussen et al., 2009) are isotopically out-ofphase with their equally-immobile invertebrate prey, likely due to rapid changes in 
invertebrate $\delta^{13} \mathrm{C}$ and $\delta^{15} \mathrm{~N}$ in response to a nutrient pulse (in this case from a trout farm located upstream of the site). A more appropriate match in this case would have been the mean value for multiple temporal samples of short-lived invertebrates at this site with the muscle tissue of the sculpin, or the comparison of a rapid turnover tissue such as liver and blood plasma in the sculpin (Dalerum and Angerbjorn 2005) with the one-time sampling of short-lived invertebrates.

Some primary consumer taxa with strict diets have relatively long development times and would therefore be more suited as isotopic baselines for top predators. These taxa include Pteronarcyidae stoneflies that shred leaf litter and water pennies (Psephenidae) that graze periphyton. Other primary consumers such as snails and algivorous crustaceans (e.g. Atyidae and Macrobrachium spp.) are relatively long-lived and can be common, particularly in tropical streams, but more information is needed about their dietary flexibility prior to their adoption as baseline organisms for food web studies. Clearly more research is also required to define the range of turnover rates in aquatic consumers, particularly from tropical and subtropical systems where data are particularly sparse.

Following from the above observations regarding elemental turnover in lowertrophic level organisms, it is not surprising that these taxa can exhibit high temporal variability. In many food web studies using isotopes in streams and rivers, singleevent sampling is conducted (e.g. Jardine et al., 2008; McHugh et al., 2010). Based on the results of the current study, whenever it is feasible organisms at the base of the food web should be sampled on multiple dates to provide an adequate representation of the potential isotopic variability at a given site (Walters and Post, 2008, Sabo et al. 2010). Budgetary considerations will largely dictate the use of this approach. If sampling locations are remote and field costs high, it may be more cost-effective to 
collect more samples and/or employ a second tracer (e.g. $\left.\delta \mathrm{D}, \delta^{34} \mathrm{~S}\right)$ during a single visit rather than make multiple visits to sites.

Our model predicts that organisms with slow turnover rates (e.g. mussels, but any equivalent taxa including benthic insects with long generation times and slow turnover rates) will show less variable responses to changes in isotope ratios at the base of the food web. Our empirical data suggest that wide fluctuations in $\delta^{13} \mathrm{C}$ of benthic algae can occur over a period as short as two weeks, most likely in response to flow events and associated changes in turbulence, dissolved $\mathrm{CO}_{2}$ concentrations (Singer et al., 2005), and productivity (Rasmussen and Trudeau, 2007). As a result, more dynamic river systems with large seasonal changes in flow (such as those from Australia shown here) are most likely to exhibit large temporal variations in algal C isotope ratios, particularly if flow ceases during prolonged dry spells, leading to high productivity and $\mathrm{CO}_{2}$ limitation in isolated pools or waterholes (Bunn et al. 2003). Conversely, more hydrologically stable systems such as those in eastern Canada may not exhibit such vast ranges in algal $\delta^{13} \mathrm{C}$ over time.

An additional drawback in using algae as an end-member in mixing models when determining the diets of consumers in streams is the possibility that the sample collected is contaminated by organic detritus. In running waters this detritus is often composed primarily of terrestrial or macrophytic material, thus shifting the $\delta^{13} \mathrm{C}$ of biofilm away from pure algae towards the $\delta^{13} \mathrm{C}$ of $\mathrm{C}_{3}$ plants (-28\%, France, 1995). Furthermore, the biofilm community growing on organic substrates (e.g. wood) tends to be more heterotrophic than that growing on inorganic substrates (e.g. rocks) (Sabater et al., 1998). These heterotrophs may use the substrate directly as a carbon source, leading to a $\delta^{13} \mathrm{C}$ value that resembles the substrate rather than the algae (Walters et al., 2007; Hladyz et al., 2011). One solution to this problem is a technique 
for purifying algae that employs colloidal silica to create a density gradient (Hamilton et al., 1992, 2005), allowing the denser detritus to settle to the bottom of a collection tube during centrifugation. Alternative approaches exist to either characterize or discriminate between algal sources within biofilm matrices, particularly in those situations where algal purifications are logistically difficult (e.g. remote sampling). Specifically, determining the chlorophyll- $a$ :C ratio of biofilm samples, coupled with $\mathrm{C}: \mathrm{N}$ ratios, can provide some indication of the degree to which biofilm samples are dominated by algal vs. other forms of carbon (Hamilton and Lewis, 1992).

Filamentous or colonial algae are often easily collected from submerged surfaces in streams and rivers with little contamination by detritus, and it is tempting to use such samples as surrogates for microalgae. However, this conspicuous material may be present largely because it is poorly digestible and thus rarely enters aquatic food webs (Bunn et al., 1999; Delong et al., 2001). Despite this limitation, filamentous algae may be worth sampling if they are consistently present and have isotope ratios that are equivalent to or correlated with those of benthic microalgae (e.g. diatoms) that are more likely to be consumed by grazers. For example, Rasmussen (2010) found that biofilm (rock scrapings) had $\delta^{13} \mathrm{C}$ that was strongly correlated $\left(r^{2}=0.77\right)$ with that of pure attached filamentous algae (Cladophora sp., etc) in temperate streams and rivers. Rasmussen (2010) also estimated that up to $33 \%$ of the carbon in biofilm was of terrestrial origin (i.e. detritus). As such, purification of biofilm using density separation techniques (Hamilton et al., 2005) may be useful in combination with sampling of filamentous algae to ascertain the true aquatic endmember for mixing models.

Given the high variability observed in algal $\delta^{13} \mathrm{C}$ through space and time at a given site, the error that this produces in mixing models, and the logistical difficulties 
in resampling baseline organisms in remote locations, an alternative method to estimate dietary source proportions (i.e. leaf litter vs. algae) is to use a gradient approach (Bunn et al., 2003; Rasmussen, 2010). To do this, collections of source and consumer material are made at many sites at a single time. The mean values at a given site for the consumer of interest are then regressed against the mean values for the source of interest (typically benthic algae). A slope close to 1 and good fit (high $r^{2}$ ) denote a strong reliance on that particular food source, and spatial and temporal variability of the source is reflected by the scatter around the line (Rasmussen, 2010). An example of this can be seen in Figure 4. Even though source and consumer $\delta^{13} \mathrm{C}$ variability was high within the data set presented here (Table 2), the average values were relatively well correlated $\left(\mathrm{r}^{2}=0.51\right)$ with a slope of 0.61 , suggesting approximately $60 \%$ contribution from benthic algae to primary consumer diet (Rasmussen, 2010). One complication in the application of this technique, however, is consumer movement. A highly mobile consumer will integrate variability among sites and thus not track site to site changes in algal $\delta^{13} \mathrm{C}$ even if benthic algae is important in the diet, resulting in a slope of zero in these plots (Rasmussen et al., 2009). The gradient approach is therefore best used when combined with some knowledge of consumer movement patterns from natural history or tagging studies.

At the site level, in many situations $\delta^{13} \mathrm{C}$ does not differ enough between food sources to allow calculation of consumer diets using mixing models. For example, in New Brunswick Canada streams, 43 of 88 sites had $\delta^{13} \mathrm{C}$ in non-purified algae that was within $2 \%$ of the value (-28\%o) for terrestrial vegetation (Jardine et al., 2008). The addition of other source tracers such as nitrogen (e.g. Udy and Bunn, 2001; Bunn et al., 2003; Reid et al., 2008), hydrogen (Doucett et al., 2007; Jardine et al., 2009b) or sulphur (Croisetiere et al., 2009) or artificial enrichment (Hamilton et al., 2001, 
2004; Pace et al., 2004; Hadwen and Bunn, 2005) may help in these situations to discern food sources for consumers. In addition, newly emerging compound-specific isotope ratio analysis can reveal both sources and transfers of nitrogen and carbon in food webs (Chikaraishi et al. 2009; Lorraine et al. 2009). However, the use of these tools comes with its own analytical, methodological and financial challenges;; hence, more research is needed to fully understand sources of variability in their application.

With all of the challenges listed herein it is perhaps surprising that SIA of stream and river food webs even works at all. Yet broad scale patterns do suggest links between consumers and their algal diet (Finlay, 2001; Rasmussen, 2010, Fig. 4) and the processes driving food web structure in streams are emerging with the aid of stable isotopes (Walters and Post, 2008; McHugh et al., 2010, Sabo et al. 2010). What is perhaps poorly represented to new users of SIA in this field is the large number of unpublished data held by numerous users of this technique (including the authors of this paper) that was deemed too difficult to interpret because of the confounding influence of the myriad of factors described above (e.g. Fig. 5). A healthy dose of realism is needed in the isotope community to convey that isotope analysis is not a silver bullet that will answer all questions about food webs in streams and rivers (and other ecosystems), but rather carries with it many equally challenging assumptions as other traditional techniques. However, by incorporating some of the recommendations listed here we anticipate improved studies that draw more accurate and robust conclusions about pure and applied issues in river and stream ecology.

\section{Acknowledgements}

The authors thank D.L. Nielsen, P.J. Suter and E.S. Krull, S. McWilliamHughes, L. Jardine, R. Diocares, M. Savoie, A. McGeachy, and C. Paton for help in 
field collections and isotope sample preparation and analysis, and two anonymous reviewers for improvements to the manuscript.

\section{References}

Anderson C, Cabana G. 2007. Estimating the trophic position of aquatic consumers in river food webs using stable nitrogen isotopes. Journal of the North American Benthological Society 26: 273-285.

Atkinson CL, Golladay SW, Opsahl SP, Covich AP. 2009. Stream discharge and floodplain connections affect seston quality and stable isotopic signatures in a coastal plain stream. Journal of the North American Benthological Society 28: $360-370$.

Atkinson CL, Opsahl SP, Covich AP, Golladay SW, Conner LM. 2010. Stable isotopic signatures, tissue stoichiometry, and nutrient cycling $(\mathrm{C}$ and $\mathrm{N})$ of native and invasive freshwater bivalves. Journal of the North American Benthological Society 29: 496-505.

Bogan AE. 1993. Fresh-water bivalve extinctions (Mollusca, Unionoida) - a search for causes. American Zoologist 33: 599-609.

Bunn SE, Davies PM, Mosisch TD. 1999. Ecosystem measures of river health and their response to riparian and catchment degradation. Freshwater Biology 41: $333-345$.

Bunn SE, Davies PM, Winning M. 2003. Sources of organic carbon supporting the food web of an arid zone floodplain river. Freshwater Biology 48: 619-635.

Bunn SE, Abal EG, Smith MJ, Choy SC, Fellows CS, Harch BD, Kennard MJ, Sheldon F. 2010. Integration of science and monitoring of river ecosystem 
health to guide investments in catchment protection and rehabilitation. Freshwater Biology 55: 223-240.

Cabana G, Rasmussen JB. 1996. Comparison of aquatic food chains using nitrogen isotopes. Proceedings of the National Academy of Sciences USA 93: 1084410847.

Chessman BC, Westhorpe DP, Mitrovic SM, Hardwick L. 2009. Trophic linkages between periphyton and grazing macroinvertebrates in rivers with different levels of catchment development. Hydrobiologia 625: 135-150.

Chikaraishi Y, Ogawa NO, Kashiyama Y, Takano Y, Suga H, Tomitani A, Miyashita H, Kitazato H, Ohkouchi N. 2009. Determination of aquatic food-web structure based on compound-specific nitrogen isotopic composition of amino acids. Limnology and Oceanography: Methods 7: 740-750.

Croisetiere L, Hare L, Tessier A, Cabana G. 2009. Sulphur stable isotopes can distinguish trophic dependence on sediments and plankton in boreal lakes. Freshwater Biology 54: 1006-1015.

Dalerum F, Angerbjorn A. 2005. Resolving temporal variation in vertebrate diets using naturally occurring stable isotopes. Oecologia 144: 647-658.

Delong MD, Thorp JH, Greenwood KS, Miller MC. 2001. Responses of consumers and food resources to a high magnitude, unpredicted flood in the upper Mississippi River basin. Regulated Rivers-Research \& Management 17: 217234.

Doi H, Kikuchi E, Takagi S, Shikano S. 2007. Changes in carbon and nitrogen stable isotopes of chironomid larvae during growth, starvation and metamorphosis Rapid Communications in Mass Spectrometry 21: 997-1002. 
Doucett RR, Marks JC, Blinn DW, Caron M, Hungate BA. 2007. Measuring terrestrial subsidies to aquatic food webs using stable isotopes of hydrogen. Ecology 88: 1587-1592.

Finlay JC. 2001. Stable-carbon-isotope ratios of river biota: implications for energy flow in lotic food webs. Ecology 82: 1052-1064.

Finlay JC. 2004. Patterns and controls of lotic algal stable carbon isotope ratios Limnology and Oceanography 49: 850-861.

Finlay JC, Power ME, Cabana G. 1999. Effects of water velocity on algal carbon isotope ratios: Implications for river food web studies. Limnology and Oceanography 44: 1198-1203.

Finlay JC, Khandwala S, Power ME. 2002. Spatial scales of carbon flow in a river food web. Ecology 83: 1845-1859.

France RL. 1995. Critical examination of stable isotope analysis as a means for tracing carbon pathways in stream ecosystems. Canadian Journal of Fisheries and Aquatic Sciences 52: 651-656.

Fry B. 2006. Stable isotope ecology, Springer, New York.

Gooderham J, Tsyrlin E. 2002. The Water Bug Book. CSIRO Publishing. 240 pp.

Gustafson L, Showers W, Kwak T, Levine J, Stoskopf M. 2007. Temporal and spatial variability in stable isotope compositions of a freshwater mussel: implications for biomonitoring and ecological studies. Oecologia 152: 140-150.

Hadwen WL, Bunn SE. 2005. Food web responses to low-level nutrient and N-15tracer additions in the littoral zone of an oligotrophic dune lake. Limnology and Oceanography 50: 1096-1105. 
Hadwen WL, Spears M, Kennard MJ. 2010. Temporal variability of benthic algal $\delta^{13} \mathrm{C}$ signatures influences assessments of carbon flows in stream food webs. Hydrobiologia 651: 239-251.

Hamilton SK, Lewis WM. 1992. Stable carbon and nitrogen isotopes in algae and detritus from the Orinoco River floodplain, Venezuela. Geochimica Et Cosmochimica Acta 56: 4237-4246.

Hamilton SK, Lewis WM, Sippel SJ. 1992. Energy sources for aquatic animals in the Orinoco River floodplain: evidence from stable isotopes. Oecologia 89: 324330.

Hamilton SK, Tank JL, Raikow DF, Wollheim WM, Peterson BJ, Webster JR. 2001. Nitrogen uptake and transformation in a midwestern U.S. stream: a stable isotope enrichment study. Biogeochemistry 54: 297-340.

Hamilton SK, Tank JL, Raikow DF, Siler ER, Dorn NJ, Leonard NE. 2004. The role of in-stream vs allochthonous $\mathrm{N}$ in stream food webs: modeling the results of an isotope addition experiment. Journal of the North American Benthological Society 23: 429-448.

Hamilton SK, Sippel SJ, Bunn SE. 2005. Separation of algae from detritus for stable isotope or ecological stoichiometry studies using density fractionation in colloidal silica. Limnology and Oceanography-Methods 3: 149-157.

Hladyz S, Nielsen DL, Suter PJ, Krull ES. 2010. Temporal variations in organic carbon utilisation by consumers in a lowland river. River Research and Applications doi: 10.1002/rra.1467.

Hladyz S, Cook RA, Petrie R, Nielsen DL. 2011. Influence of substratum on the variability of benthic biofilm stable isotope signatures: implications for energy flow to a primary consumer. Hydrobiologia doi: 10.1007/s10750-010-0593-0. 
Hobson KA, Clark RG. 1992. Assessing avian diets using stable isotopes 1. Turnover of ${ }^{13} \mathrm{C}$ in tissues. Condor $94: 181-188$.

Howard JK, Cuffey KM, Solomon M. 2005. Toward using Margaritifera falcata as an indicator of base level nitrogen and carbon isotope ratios: insights from two California Coast Range rivers. Hydrobiologia 541: 229-236.

Jardine TD, Curry RA, Heard KS, Cunjak RA. 2005. High fidelity: isotopic relationship between stream invertebrates and their gut contents. Journal of the North American Benthological Society 24: 290-299.

Jardine TD, Kidd KA, Fisk AT. 2006. Applications, considerations, and sources of uncertainty when using stable isotope analysis in ecotoxicology. Environmental Science \& Technology 40: 7501-7511.

Jardine TD, Kidd KA, Polhemus JT, Cunjak RA. 2008. An elemental and stable isotope assessment of water strider feeding ecology and lipid dynamics: synthesis of laboratory and field studies. Freshwater Biology 53: 2192-2205.

Jardine TD, Roussel J-M, Mitchell SC, Cunjak RA. 2009a. Detecting marine nutrient and organic matter inputs into multiple trophic levels in streams of Atlantic Canada and France. pp. 427-445. In Haro, A., Smith, K.L., Rulifson, R.A., Moffitt, C.M., Klauda, R.J., Dadswell, M.J., Cunjak, R.A., Cooper, J.E., Beal, K.L., and Avery, T.S. (eds) Challenges for Diadromous Fishes in a Dynamic Global Environment. American Fisheries Society, Symposium 69, Bethesda, Maryland.

Jardine TD, Kidd KA, Cunjak RA. 2009b. An evaluation of deuterium as a food source tracer in temperate streams of eastern Canada. Journal of the North American Benthological Society 28: 885-893. 
Jennings S, Warr KJ, Mackinson S. 2002. Use of size-based production and stable isotope analyses to predict trophic transfer efficiencies and predator-prey body mass ratios in food webs. Marine Ecology Progress Series 240: 11-20.

Lock MA. 1981. River epilithon - a light and organic energy transducer. In Lock, M.A and D.D. Williams (eds), Perspectives in running water ecology. Plenum, New York: 3-40.

Lorraine A, Graham B, Menard F, Popp B, Bouillon S, van Berugel P, Cherel Y. 2009. Nitrogen and carbon isotope values of individual amino acids: a tool to study foraging ecology of penguins in the Southern Ocean. Marine Ecology Progress Series 391: 293-306.

McCutchan JH, Lewis WM. 2002. Relative importance of carbon sources for macroinvertebrates in a Rocky Mountain stream. Limnology and Oceanography 47: 742-752.

McHugh PA, Mcintosh AR, Jellyman PG. 2010. Dual influences of ecosystem size and disturbance on food chain length in streams. Ecology Letters 13: 881-890.

Mcintyre PB, Flecker AS. 2006. Rapid turnover of tissue nitrogen of primary consumers in tropical freshwaters. Oecologia 148: 12-21.

Merritt RW, Cummins KW. 1996. An introduction to the aquatic insects of North America.

Mulholland PJ, Tank JL, Sanzone DM, Wollheim WM, Peterson BJ, Webster JR, Meyer JL. 2000. Nitrogen cycling in a forest stream determined by a ${ }^{15} \mathrm{~N}$ tracer addition. Ecological Monographs 70: 471-493.

Olsson K, Stenroth P, Nystrom P, Graneli W. 2009. Invasions and niche width: does niche width of an introduced crayfish differ from a native crayfish? Freshwater Biology 54: 1731-1740. 
O'Reilly CM, Hecky RE, Cohen AS, Plisnier PD. 2002. Interpreting stable isotopes in food webs: Recognizing the role of time averaging at different trophic levels. Limnology and Oceanography 47: 306-309.

Ostrom NE, Knoke KE, Hedin LO, Robertson GP, Smucker AJM. 1998. Temporal trends in nitrogen isotope values of nitrate leaching from an agricultural soil. Chemical Geology 146: 219-227.

Overmyer JP, MacNeil MA, Fisk AT. 2008. Fractionation and metabolic turnover of carbon and nitrogen stable isotopes in blackfly larvae. Rapid Communications in Mass Spectrometry 22: 694-700.

Pace ML, Cole JJ, Carpenter SR, Kitchell JF, Hodgson JR, Van De Bogert MC, Bade DL, Kritzberg ES, Bastviken D. 2004. Whole-lake carbon-13 additions reveal terrestrial support of aquatic food webs. Nature 427: 240-243.

Post DM. 2002. Using stable isotopes to estimate trophic position: models, methods and assumptions. Ecology 83: 703-718.

Post DM, Pace ML, Hairston NGJ. 2000. Ecosystem size determines food-chain length in lakes. Nature 405: 1047-1049.

Perry RW, Bradford MJ, Grout JA. 2003. Effects of disturbance on contribution of energy sources to growth of juvenile chinook salmon (Oncorhynchus tshawytscha) in boreal streams. Canadian Journal of Fisheries and Aquatic Sciences 60: 390-400.

Puckridge JT, Sheldon F, Walker KF, Boulton AJ. 1998. Flow variability and the ecology of large rivers. Marine and Freshwater Research 49: 55-72.

Raikow DF, Hamilton SK. 2001. Bivalve diets in a midwestern U.S. stream: A stable isotope enrichment study. Limnology and Oceanography 46: 514-522. 
Rasmussen JB. 2010. Estimating terrestrial contribution to stream invertebrates and periphyton using a gradient-based mixing model for $\delta^{13}$ C. Journal of Animal Ecology 79: 393-402.

Rasmussen JB, Trudeau V, Morinville G. 2009. Estimating the scale of fish feeding movements in rivers using $\delta^{13} \mathrm{C}$ signature gradients. Journal of Animal Ecology 78: 674-685.

Rasmussen JB, Trudeau V. 2007. Influence of velocity and chlorophyll standing stock on periphyton $\delta^{13} \mathrm{C}$ and $\delta^{15} \mathrm{~N}$ in the Ste. Marguerite River system, Quebec. Canadian Journal of Fisheries and Aquatic Sciences 64: 1370-1381.

Rasmussen JB, Trudeau V. 2010. How well are velocity effects on $\delta^{13} \mathrm{C}$ signatures transmitted up the food web from algae to fish? Freshwater Biology 55: 13031314.

Reid DJ, Quinn GP, Lake PS, Reich P. 2008. Terrestrial detritus supports the food webs in lowland intermittent streams of south-eastern Australia: a stable isotope study Freshwater Biology 53: 2036-2050.

Sabater S, Gregory SV, Sedell JR. 1998. Community dynamics and metabolism of benthic algae colonizing wood and rock substrata in a forest stream. Journal of Phycology 34: 561-567.

Sabo JL, Finlay JC, Kennedy T, Post DM. 2010. The role of discharge variation in scaling of drainage area and food chain length in rivers. Science 330: 965-967.

Singer GA, Panzenbock M, Weigelhofer G, Marchesani C, Waringer J, Wanek W, Battin TJ. 2005. Flow history explains temporal and spatial variation of carbon fractionation in stream periphyton. Limnology and Oceanography 50: 706712. 
Spears M. 2007. Honours Thesis. Griffith University.

Tsoi WY. 2008. Honours Thesis. Griffith University.

Udy JW, Bunn SE. 2001. Elevated delta N-15 values in aquatic plants from cleared catchments: why? Marine and Freshwater Research 52: 347-351.

Vander Zanden MJ, Rasmussen JB. 1999. Primary consumer $\delta^{13} \mathrm{C}$ and $\delta^{15} \mathrm{~N}$ and the trophic position of aquatic consumers. Ecology 80: 1395-1404.

Walters DM, Fritz KM, Phillips DL. 2007. Reach-scale geomorphology affects organic matter and consumer $\delta^{13} \mathrm{C}$ in a forested Piedmont stream. Freshwater Biology 52: 1105-1119.

Walters DM, Fritz KM, Johnson BR, Lazorchak JM, Mccormick FH. 2008. Influence of trophic position and spatial location on polychlorinated biphenyl (PCB) bioaccumulation in a stream food web. Environmental Science and Technology 42: 2316-2322.

Walters AW, Post DM. 2008. An experimental disturbance alters fish size structure but not food chain length in streams. Ecology 89: 3261-3267.

Wolf N, Carleton SA, Martinez Del Rio CM. 2009. Ten years of experimental animal isotopic ecology. Functional Ecology 23: 17-26. 
Table 1. Half-lives (the time to $50 \%$ change in isotope ratio following a switch in nutrient or food source) for various food web components in streams. Consumer data represent whole-body samples except in the case of mussels Pleurobema sintoxia and crayfish Oronectes propinquus where data are for muscle and digestive gland.

\begin{tabular}{|c|c|c|c|c|c|}
\hline $\begin{array}{l}\text { Common } \\
\text { name }\end{array}$ & Scientific name & Isotope & $\begin{array}{l}\text { Turnover } \\
\text { rate }\left(\text { day }^{-1}\right)\end{array}$ & $\begin{array}{c}\begin{array}{c}\text { Half-life } \\
\text { (days) }\end{array} \\
\end{array}$ & Reference \\
\hline \multicolumn{6}{|c|}{$\underline{\text { Primary producers }}$} \\
\hline Algae & algae in epilithon & $\delta^{15} \mathrm{~N}$ & 0.07 & 8.9 & Hamilton et al., 2001 \\
\hline biofilm & epilithon & $\delta^{15} \mathrm{~N}$ & & 11.8 & Mulholland et al., 20 \\
\hline \multicolumn{6}{|c|}{ Heterotrophic bacteria } \\
\hline microbes & microbes in leaves & $\delta^{15} \mathrm{~N}$ & 0.22 & 2.9 & Hamilton et al., 2001 \\
\hline microbes & microbes in FBOM & $\delta^{15} \mathrm{~N}$ & 0.14 & 4.6 & Hamilton et al., 2001 \\
\hline
\end{tabular}

Primary consumers/Omnivores

\begin{tabular}{|c|c|c|c|c|c|}
\hline blackflies & Simuliidae & $\delta^{15} \mathrm{~N}$ & & $1.5 \pm 0.2$ & Overmyer et al., 2008 \\
\hline blackflies & Simuliidae & $\delta^{15} \mathrm{~N}$ & 0.26 & 2.3 & Hamilton et al., 2004 \\
\hline mayflies & Baetis & $\delta^{15} \mathrm{~N}$ & 0.22 & 2.9 & Hamilton et al., 2004 \\
\hline mussels $^{\mathrm{a}}$ & Pleurobema sintoxia & $\delta^{15} \mathrm{~N}$ & 0.16 & 4.1 & Hamilton et al., 2004 \\
\hline caddisflies & Hydropsychidae & $\delta^{15} \mathrm{~N}$ & 0.15 & 4.3 & Hamilton et al., 2004 \\
\hline crayfish $^{\mathrm{b}}$ & Oronectes propinquus & $\delta^{15} \mathrm{~N}$ & 0.15 & 4.6 & Hamilton et al., 2004 \\
\hline crayfish $^{\mathrm{c}, \mathrm{d}}$ & Oronectes propinquus & $\delta^{15} \mathrm{~N}$ & 0.13 & 5.3 & Hamilton et al., 2004 \\
\hline mayflies & Stenonema + Stenacron & $\delta^{15} \mathrm{~N}$ & 0.12 & 5.3 & Hamilton et al., 2004 \\
\hline midges & Chironomidae & $\delta^{13} \mathrm{C}$ & & $\sim 6$ & Doi et al., 2007 \\
\hline $\begin{array}{l}\text { midges } \\
\text { Beetle }\end{array}$ & Chironomidae & $\delta^{15} \mathrm{~N}$ & & $\sim 6$ & Doi et al., 2007 \\
\hline larvae & Psephenus & $\delta^{15} \mathrm{~N}$ & 0.06 & 11.0 & Hamilton et al., 2004 \\
\hline $\begin{array}{l}\text { amphipods } \\
\text { Beetle }\end{array}$ & Gammarus & $\delta^{15} \mathrm{~N}$ & 0.06 & 11.6 & Hamilton et al., 2004 \\
\hline larvae & Elmidae & $\delta^{15} \mathrm{~N}$ & 0.03 & 21.0 & $\begin{array}{l}\text { Hamilton et al., } 2004 \\
\text { McIntyre and Flecker, }\end{array}$ \\
\hline Snails & Tarebia granifera & $\delta^{15} \mathrm{~N}$ & $0.03,0.01$ & $20.2,49.5$ & 2006 \\
\hline mussels $^{\mathrm{e}}$ & Elliptio complanata & $\delta^{15} \mathrm{~N}$ & & 113.0 & Gustafson et al., 2007 \\
\hline mussels $^{\mathrm{d}}$ & Pleurobema sintoxia & $\delta^{15} \mathrm{~N}$ & 0.003 & 231.1 & Hamilton et al., 2004 \\
\hline
\end{tabular}

adigestive gland, ${ }^{\mathrm{b}}$ juveniles, ${ }^{\mathrm{c}}$ adults, ${ }^{\mathrm{d}}$ muscle, ${ }^{\mathrm{e}}$ haemolymph 
Table 2. Annual mean \pm S.D. and range in $\delta^{13} \mathrm{C}$ and $\delta^{15} \mathrm{~N}$ for aquatic primary producers (algae, biofilm) and primary consumers (benthic invertebrates) from streams and rivers sampled seasonally in Australia and Canada. All Canadian sites (references a and b) are in a temperate climate, while the Australian sites are located in temperate (refs c and f) and subtropical climates (refs d and e).

\begin{tabular}{|c|c|c|c|c|c|c|c|c|c|c|c|}
\hline \multirow[b]{3}{*}{ Site } & \multirow{3}{*}{$\begin{array}{c}\text { No. of } \\
\text { sample } \\
\text { dates }\end{array}$} & \multirow[b]{3}{*}{ Frequency (duration) } & \multicolumn{4}{|c|}{$\delta^{13} \mathrm{C}$} & \multicolumn{4}{|c|}{$\delta^{15} \mathrm{~N}$} & \multirow[b]{3}{*}{ Ref } \\
\hline & & & \multicolumn{2}{|c|}{$1^{\circ}$ producers } & \multicolumn{2}{|c|}{$1^{\circ}$ consumers } & \multicolumn{2}{|c|}{$1^{\circ}$ producers } & \multicolumn{2}{|c|}{$1^{\circ}$ consumers } & \\
\hline & & & Mean (SD) & Range & Mean (SD) & Range & $(\mathrm{SD})$ & Range & Mean (SD) & Range & \\
\hline \multicolumn{12}{|l|}{$\underline{\text { Canadian sites }}$} \\
\hline Corbett Brook & 8 & bi-weekly (May-Oct ’07) & $-28.3(1.3)$ & 1.6 & $-29.7(2.4)$ & 5.4 & $3.0(0.9)$ & 2.2 & $4.4(1.1)$ & 2.5 & a \\
\hline English Brook & 10 & bi-weekly (May-Oct ’07) & $-27.9(1.6)$ & 3.9 & $-28.5(1.6)$ & 3.8 & $3.1(0.6)$ & 1.6 & $5.2(1.1)$ & 3 & a \\
\hline McKenzie Brook & 10 & bi-weekly (May-Oct '07) & $-26.7(2.7)$ & 6.7 & $-27.7(1.4)$ & 3.2 & $2.1(0.6)$ & 1.2 & $3.7(1.1)$ & 2.2 & $\mathrm{a}$ \\
\hline Parks Brook & 10 & $\begin{array}{l}\text { bi-weekly (May-Oct '07) } \\
\text { weekly/bi-weekly (May- }\end{array}$ & $-32.9(2.0)$ & 3.6 & $-34.6(2.8)$ & 3.9 & $4.1(1.0)$ & 2.1 & $5.1(0.9)$ & 1.1 & $\mathrm{a}$ \\
\hline Doctor's Brook 1 & 9 & Sept ’07) & $-28.4(1.1)$ & 3.1 & $-30.4(2.0)$ & 5.3 & $4.0(1.0)$ & 3.2 & $3.7(0.9)$ & 2.5 & $\mathrm{~b}$ \\
\hline Doctor's Brook 2 & 6 & tri-weekly (May-Sept ‘07) & $-28.2(0.7)$ & 1.8 & $-28.5(1.6)$ & 3.1 & $2.6(1.4)$ & 3.9 & $1.6(1.2)$ & 2.4 & $\mathrm{~b}$ \\
\hline \multicolumn{12}{|l|}{ Australian sites } \\
\hline Murrumbidgee River 1 & 5 & variable (Sept '00-Nov '01) & $-28.3(2.2)$ & 5.8 & $-29.5(1.8)$ & 4.7 & $11.2(0.7)$ & 1.9 & $11.9(1.7)$ & 4.2 & $\mathrm{c}$ \\
\hline Murrumbidgee River 2 & 7 & variable (Feb '00-Nov '01) & $-26.8(0.9)$ & 2.8 & $-28.8(1.1)$ & 3.3 & $10.9(2.0)$ & 5.9 & $12.2(2.4)$ & 5.2 & $\mathrm{c}$ \\
\hline Tumut River 1 & 3 & variable (Oct '00-Aug '01) & $-27.5(2.2)$ & 4.4 & $-29.8(4.4)$ & 8.6 & $5.3(1.1)$ & 2.2 & $4.9(1.1)$ & 2.0 & c \\
\hline Tumut River 2 & 4 & variable (May '00-Aug '01) & $-28.0(1.5)$ & 3.4 & $-29.3(3.2)$ & 7.2 & $6.1(0.9)$ & 2.1 & $5.3(1.7)$ & 3.7 & $\mathrm{c}$ \\
\hline Goobarragandra River 1 & 7 & variable (Feb '00-Nov '01) & $-25.9(0.8)$ & 2.4 & $-25.7(1.6)$ & 4.1 & $3.0(0.9)$ & 1.9 & $3.0(0.8)$ & 2.6 & $\mathrm{c}$ \\
\hline
\end{tabular}




\begin{tabular}{|c|c|c|c|c|c|c|c|c|c|c|c|}
\hline Goobarragandra River 2 & 5 & variable (Aug '00-Nov '01) & $-26.0(1.0)$ & 2.5 & $-26.3(0.8)$ & 1.9 & $1.5(1.5)$ & 3.8 & $0.6(0.2)$ & 0.5 & $\mathrm{c}$ \\
\hline Goodradigbee River 1 & 7 & variable (Feb '00-Nov '01) & $-26.6(0.9)$ & 2.9 & $-26.3(1.1)$ & 3.3 & $1.8(0.4)$ & 1.0 & $0.9(0.4)$ & 0.9 & $\mathrm{c}$ \\
\hline Goodradigbee River 2 & 5 & variable (Sept '00-Nov '01) & $-26.0(1.2)$ & 3.4 & $-26.5(1.5)$ & 3.8 & $1.9(0.6)$ & 1.3 & $1.6(0.7)$ & 1.8 & $\mathrm{c}$ \\
\hline Stockyard Creek & 8 & weekly (Feb-April '07) & $-24.8(2.7)$ & 8.1 & N/A & N/A & $0.0(0.8)$ & 2.7 & N/A & N/A & $\mathrm{d}$ \\
\hline Left Hand Branch & 8 & weekly (Feb-April '07) & $-24.7(1.0)$ & 3.2 & N/A & N/A & $1.4(0.6)$ & 1.8 & N/A & N/A & $\mathrm{d}$ \\
\hline Lost World & 8 & weekly (Feb-April '07) & $-25.3(0.9)$ & 2.9 & N/A & N/A & $0.6(0.4)$ & 1.0 & N/A & N/A & $\mathrm{d}$ \\
\hline Widgee Creek & 8 & weekly (Feb-April '07) & $-23.6(1.8)$ & 6.0 & N/A & N/A & $4.2(0.6)$ & 2.2 & N/A & N/A & $\mathrm{d}$ \\
\hline Christmas Creek & 8 & weekly (Feb-April '07) & $-27.0(1.5)$ & 4.5 & N/A & N/A & $2.7(0.6)$ & 1.9 & N/A & N/A & $\mathrm{d}$ \\
\hline Blunder Creek & 8 & weekly (Jan-March '08) & $-34.3(3.8)$ & 11.7 & $-35.8(1.9)$ & 8.2 & $5.0(2.1)$ & 7.4 & $4.8(2.3)$ & 8.7 & $\mathrm{e}$ \\
\hline Moolabin Creek & 8 & weekly (Jan-March '08) & $-27.2(1.5)$ & 5.6 & $-27.1(1.8)$ & 6.0 & $8.1(0.8)$ & 3.3 & $9.4(1.3)$ & 4.0 & $\mathrm{e}$ \\
\hline Stable Swamp Creek & 8 & weekly (Jan-March '08) & $-36.5(4.2)$ & 14.3 & $-29.0(1.3)$ & 4.5 & $8.6(0.9)$ & 3.4 & $8.2(0.4)$ & 1.4 & $\mathrm{e}$ \\
\hline Sheep Station Gully & 8 & $\begin{array}{c}\text { weekly (Jan-March '08) } \\
\text { bi-monthly (May } 07 \text { - May }\end{array}$ & $-31.5(1.6)$ & 13.6 & $-29.4(1.6)$ & 4.7 & $5.6(1.6)$ & 5.4 & $9.4(1.4)$ & 4.3 & $\mathrm{e}$ \\
\hline Ovens River 1 & 7 & $\begin{array}{c}08 \text { ) } \\
\text { bi-monthly (May } 07 \text { - May }\end{array}$ & $-25.4(4.9)$ & 14.5 & $-27.7(1.1)$ & 3.2 & $4.7(1.3)$ & 4.1 & $9.9(1.4)$ & 3.9 & $\mathrm{f}$ \\
\hline Ovens River 2 & 7 & $08)$ & $-26.4(3.2)$ & 14.8 & $-26.9(2.5)$ & 10.1 & $3.8(0.7)$ & 3.3 & $6.2(1.6)$ & 5.8 & $\mathrm{f}$ \\
\hline
\end{tabular}

athis study, ${ }^{\mathrm{b}} \mathrm{Jardine}$ et al., 2009a, ${ }^{\mathrm{c}}$ Chessman et al., 2009, ${ }^{\mathrm{d}}$ Spears 2007, ${ }^{\mathrm{e}}$ Tsoi 2008, ${ }^{\mathrm{f}}$ Hladyz et al., 2010 
$1 \quad$ Figure legends

2 Figure 1. Dynamics of $\delta^{15} \mathrm{~N}$ in stream algae and primary consumers during and after a

3 hypothetical step change in the $\delta^{15} \mathrm{~N}$ of the dissolved $\mathrm{N}$ source that lasts for 30 days.

4 Responses are based on a compartment model and typical consumer $\mathrm{N}$ turnover rates

5 for a woodland stream in Michigan (USA), as observed during a summer ${ }^{15} \mathrm{~N}$ addition

6 experiment (Hamilton et al. 2001, 2004; Raikow and Hamilton 2001).

8 Figure 2. Illustrative examples of streams with low (English Brook, New Brunswick

9 Canada, solid circles) and high (Stockyard Creek, Queensland Australia, open

10 triangles) algal isotopic variability in space and time for $\delta^{13} \mathrm{C}(\mathrm{A})$ and $\delta^{15} \mathrm{~N}(\mathrm{~B})$.

11 Means for the period of study ( \pm standard deviation) are shown for the two streams.

13 Figure 3. Relationship between the site-specific range in $\delta^{13} \mathrm{C}(\mathrm{A})$ and $\delta^{15} \mathrm{~N}(\mathrm{~B})$ of

14 primary producers versus that of primary consumers in Australia and Canada (data

15 from Table 2). Each point represents the maximum minus the minimum value within

16 a site that was sampled multiple times.

18 Figure 4. Relationship between the overall site-specific mean $\delta^{13} \mathrm{C}(\mathrm{A})$ and $\delta^{15} \mathrm{~N}(\mathrm{~B})$

19 of primary producers versus that of primary consumers. Each point represents a site

20 sampled multiple times in Australia and Canada (data from Table 2).

22 Figure 5. An example of a poor isotopic "match" between a consumer (the benthic

23 invertivore sculpin) and its invertebrate prey in a French river (Kerlegan Brook).

$24 \quad$ Modified from Jardine et al. 2009. 
Figure 1.

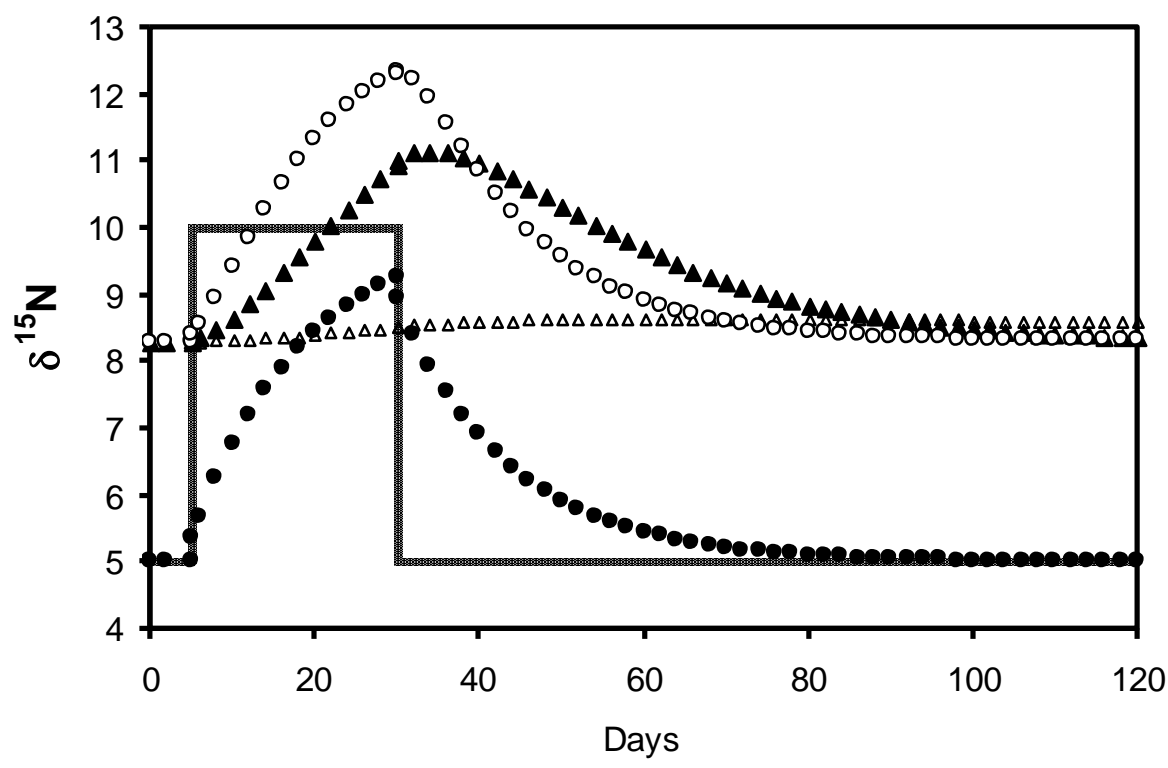

Dissolved $\mathrm{N}$ source

- $\quad$ Algae $\mathrm{k}=0.07 / \mathrm{d}$

\Beetle larva $k=0.06 / d \Delta$ Mussel $k=0.003 / d$

- Mayfly k $=0.26 / \mathrm{d}$ 
Figure 2.
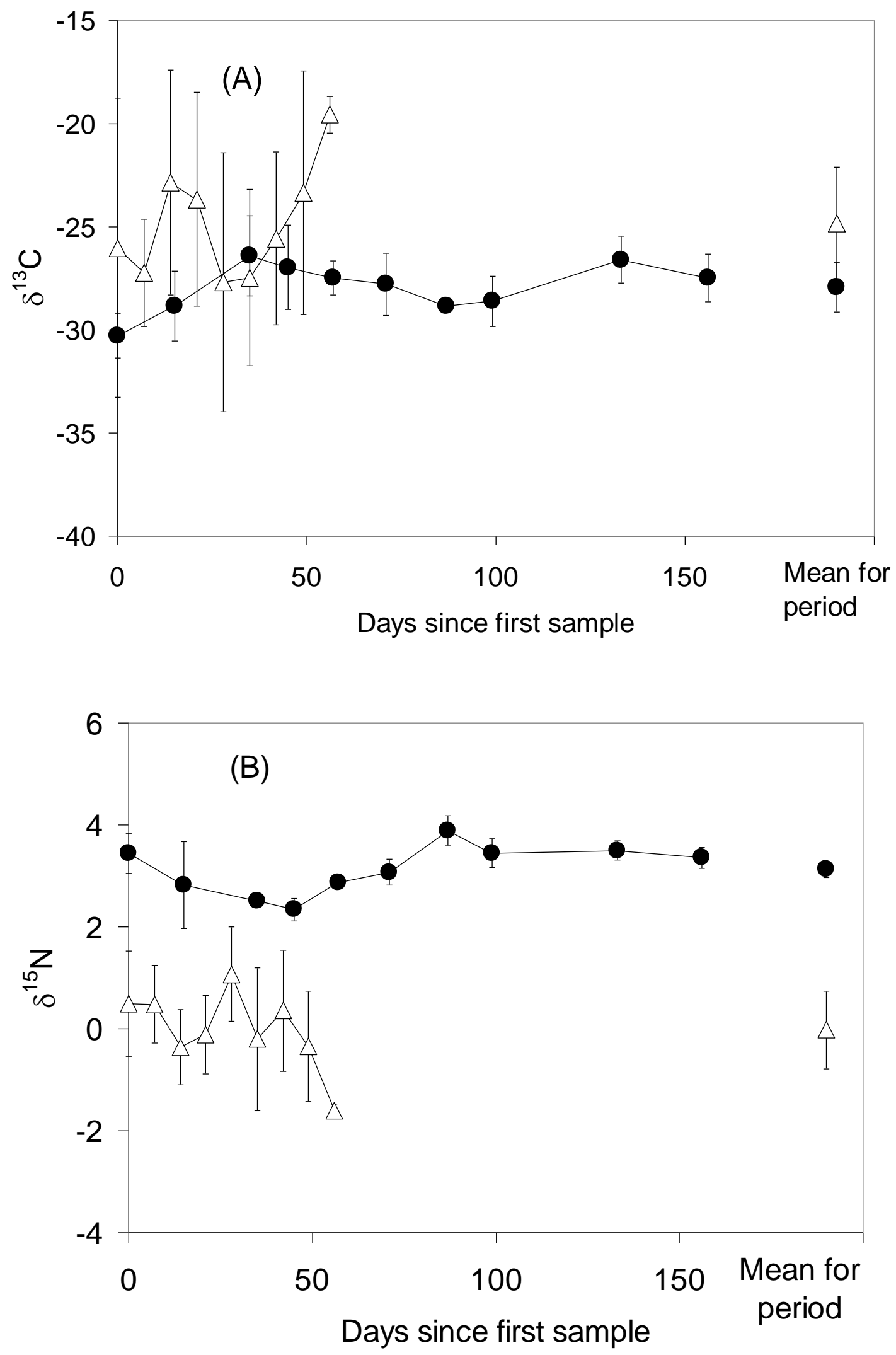
Figure 3

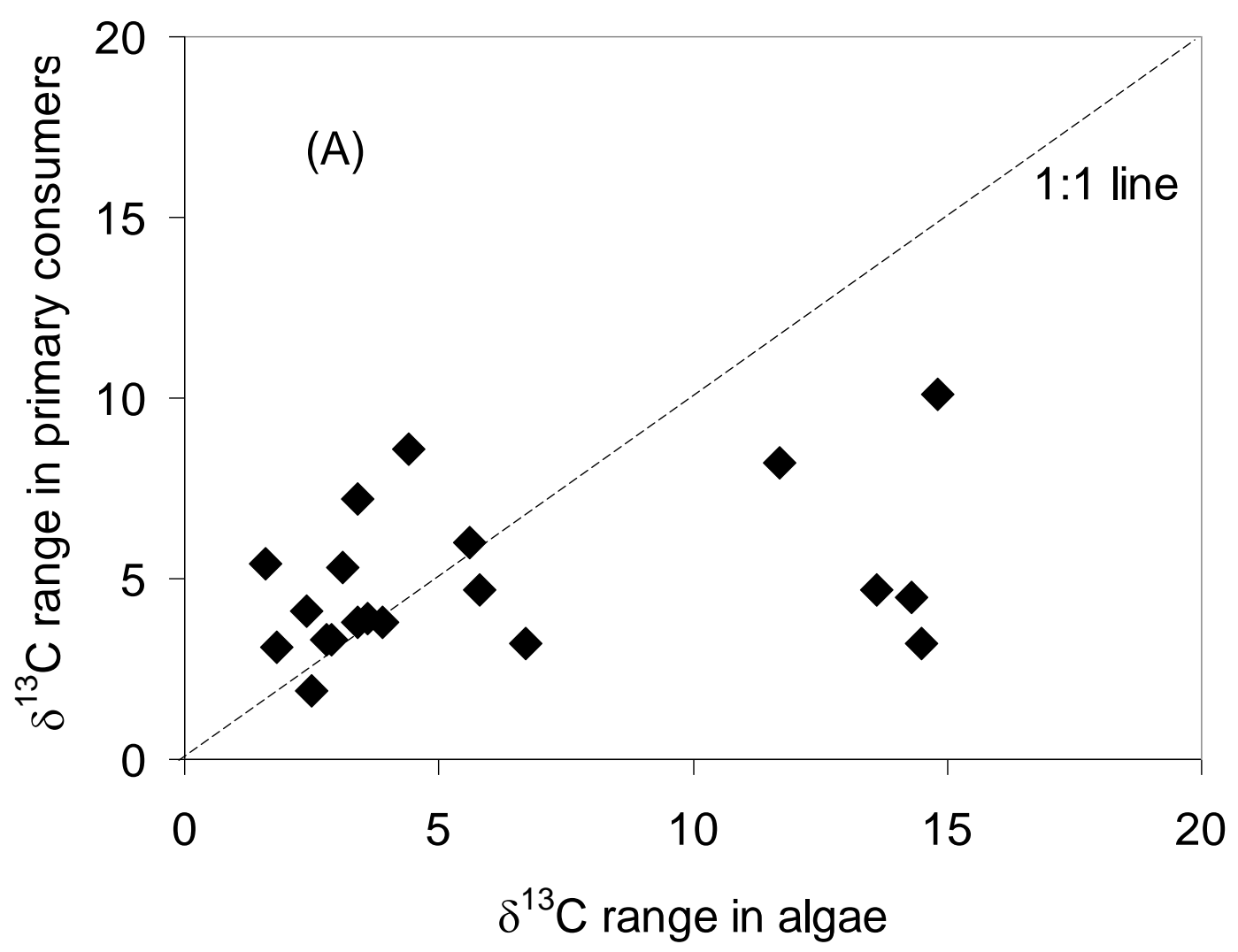

46

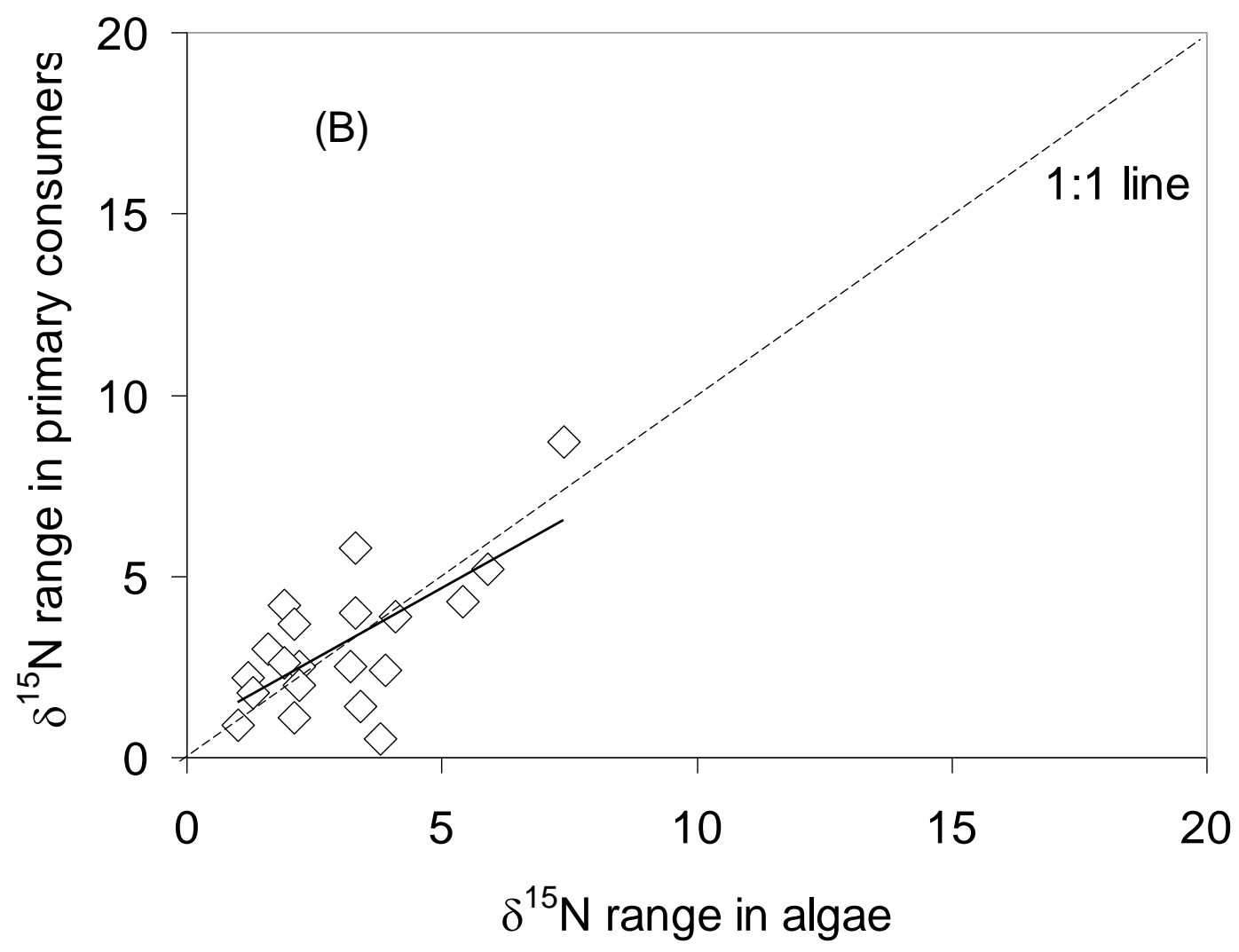


Figure 4.
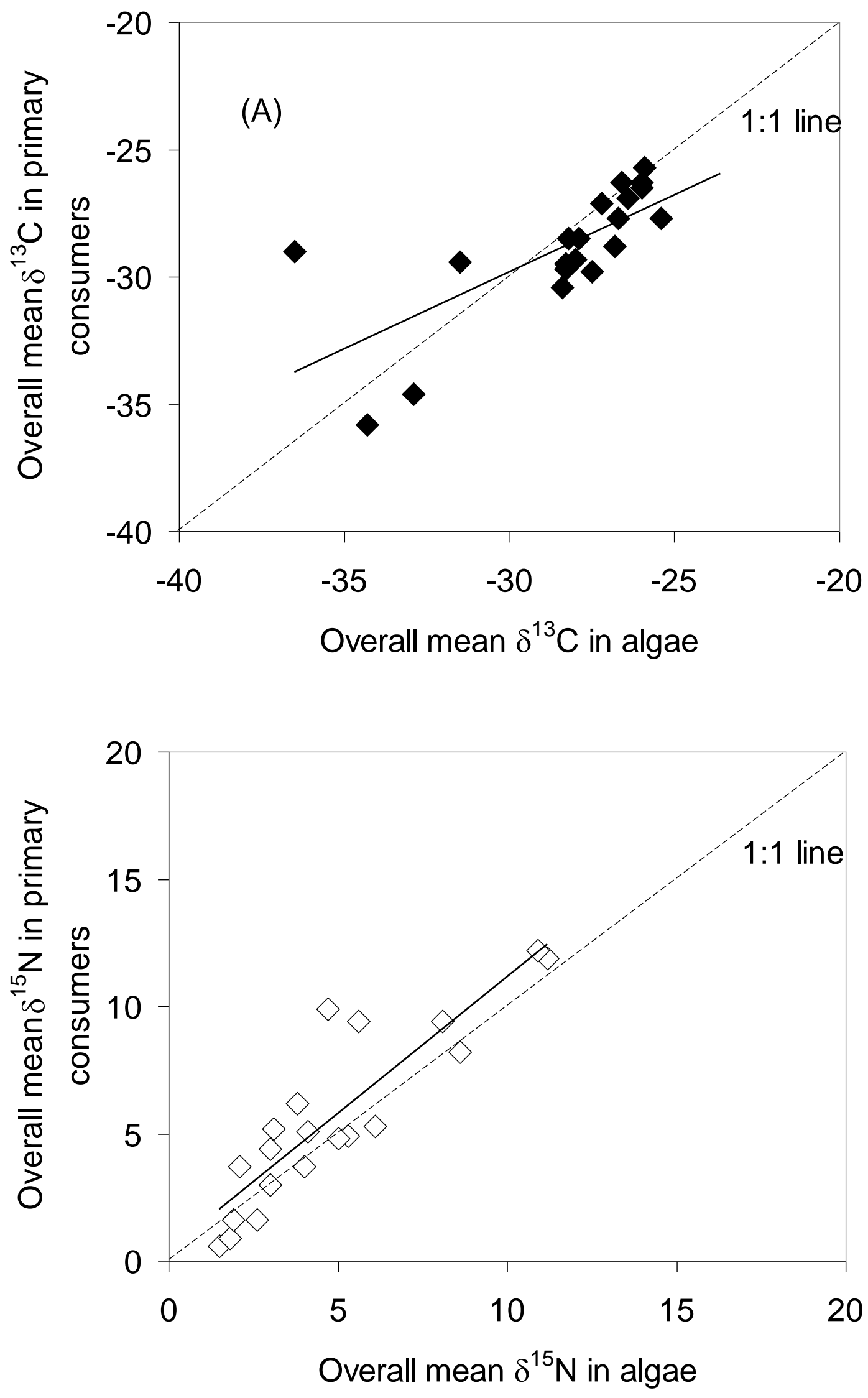
$51 \quad$ Figure 5.

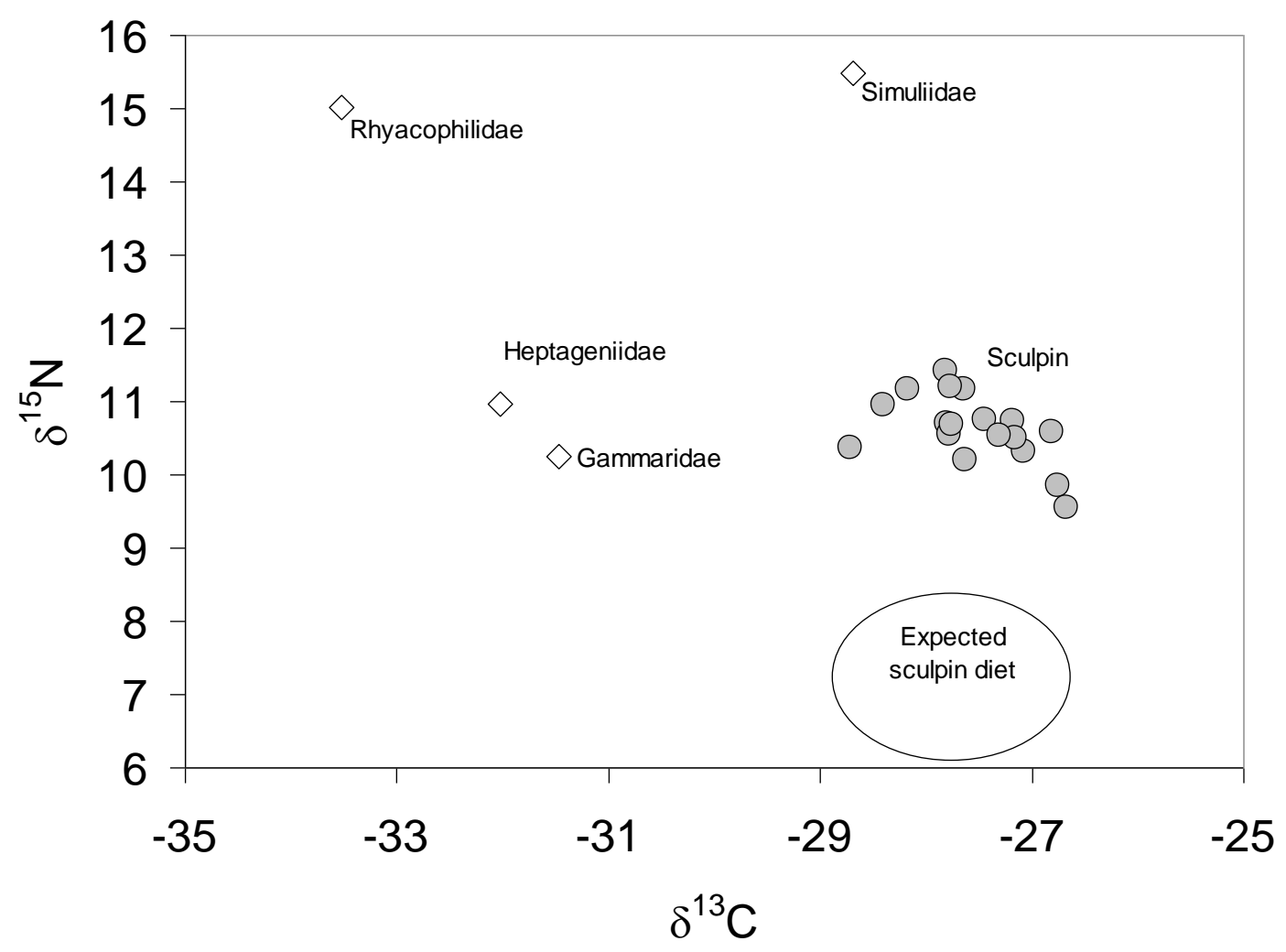

52 